To Maega | Jurnal Pengabdian Masyarakat

Februari-2022, Vol.5, No.1, hal, 24-33

$\operatorname{ISSN}(P): 2622-6332 ; \operatorname{ISSN}(E): 2622-6340$

http://www.ojs.unanda.ac.id/index.php/tomaega

\title{
Gerakan Desa Peduli Terhadap Cara Membuang Sampah Masker Sekali Pakai Di Desa Cikelet
}

\author{
Novriyanti Lubis ${ }^{1 *}$, Novita Rosalia' ${ }^{1}$, Sution${ }^{1}$, Putri Widia1, Robi Asran \\ Nugraha1, Syifa Aladawi1, Ikbal Taufikurohman² \\ ${ }^{1}$ Program Studi Farmasi, Fakultas Matematika dan Ilmu Pengetahuan Alam, Universitas \\ Garut, Jalan Jati No 42 B, Tarogong Kaler Garut \\ 2 Program Studi Agroteknologi, Fakultas Pertanian, Universitas Garut, Jalan Samarang, Garut \\ *Correspondent Email: novriyantilubis@uniga.ac.id
}

\section{Article History:}

Received: 18-10-2021; Received in Revised: 05-11-2021; Accepted: 17-11-2021

DOI: http://dx.doi.org/10.35914/tomaega.v5i1.920

\begin{abstract}
Abstrak
Wabah Covid 19 mewajibkan setiap orang untuk senantisa menggunakan masker sebagai bentuk tahap awal protokol kesehatan. Kegiatan PKM dilaksanakan dengan memberikan penyuluhan melalui brosur kepada warga desa Cikelet dan untuk mengetahui tingkat pemahamannya dilakukan pre and post test. Menurut hasil survei dari 127 warga yang mengikuti sosialisasi 20,5\% warga desa tersebut menggunakan masker sekali pakai dan 46,5\% terkadang masker kain dan masker sekali pakai untuk kegiatan sehari-harinya ketika beraktivitas di luar rumah. Jika hal tersebut berlangsung secara lama maka akan menyebabkan masalah baru khususnya mengenai sampah maskenya apabila tidak dibuang dengan cara yang baik dan benar. Kelompok 4 KKN desa Cikelet khususnya dari tim Farmasi Universitas Garut telah memberikan penyuluhan terhadap warga sekitar melalui media brosur dengan tema "Cara membuang sampah masker sekali pakai". Kegiatan sosialisasi diawali denga pre test, penyuluhan, dan post test. Hasil kegiatan menunjukkan adanya peningkatan kesadaran dan pengetahuan warga untuk membuang sampah masker sekai pakai dengan cara yang baik dan benar.
\end{abstract}

Kata Kunci: Sampah masker, penyuluhan kesehatan, desa Cikelet

\begin{abstract}
The Covid-19 outbreak requires everyone to always wear a mask as a form of the initial stage of the health protocol. PKM activities are carried out by providing counseling through brochures to residents of Cikelet village and to determine the level of understanding, pre and post tests are carried out. In Cikelet village, according to the survey results from 127 residents who participated in the socialization, 20.5\% of the villagers used medical masks, and 46.5\% sometimes cloth masks and medical masks for their daily activities when they were outside the home. If this goes on for a long time, it will cause new problems, especially regarding the medical mask waste if it is not disposed of in a good and right way. Group 4 KKN Cikelet village, especially from the Garut University Pharmacy team, has provided counseling to local residents through brochures with the theme "How to dispose of medical mask waste". The socialization activity begins with pretest, counseling, and post-test. The results of the activity show that there is an increase in the awareness and knowledge of residents to dispose of medical mask waste in a good and correct way.

Keywords: Mask waste, health education, Cikelet village
\end{abstract}




\section{Pendahuluan}

Sejak wabah virus Covid 19 melanda dunia, masker menjadi suatu alat yang wajib digunakan oleh seseorang agar bisa mencegah penularan virus dan tentu hal ini menjadi sangat berbahaya. Untuk itu WHO yang merupakan organisasi kesehatan dunia telah mewajibkan penggunaannya. Menurut data yang telah berhasil dikumpulkan oleh pihak BBC secara global, penduduk dunia telah mempergunakan 129 milyar masker sekali pakai setiap bulannya selama pandemi ini. Jika satu bulan terdapat 31 hari, maka penggunaan rata-rata masker sekali pakai di dunia sekitar 2,8 juta masker per menit, menurut penelitian yang dipublikasikan di jurnal Frontiers of Environmental Science and Engineering (Saptoyo, 2021).

Pandemi Covid-19 membuat sampah masker menjadi gelombang sampah baru untuk polusi lingkungan (Piat, 2021). Namun penggunaan masker sekali pakai ini di lingkungan masyarakat tidak dapat digolongkan sebagai limbah medis yang harus dipandang seperti limbah medis di Fasilitas pelayanan kesehatan (Inferm, 2021). Limbah masker yang umumnya digunakan oleh masyarakat seperti ini dimasukkan ke dalam jenis limbah domestik, dengan demikian dianggap pengelolaan nantinya sama dengan pengelolaan limbah domestik sesuai Undang Undang republik Indonesia dengan Nomor 18 tahun 2008 tentang pengelolaan sampah. Diantara faktor yang menjadi salah satu pemicu masalah sampah adalah pertumbuhan penduduk Indonesia yang sangat pesat (Azizah, 2012), penanganan sampah yang belum optimal dikendalikan oleh negara dan upaya daur ulang sampah oleh masyarakat belum maksimal dilaksanakan (Didiharyono dkk, 2018).

Desa Cikelet adalah salah satu desa yang ada di Jawa barat, tepatnya di Kabupaten Garut. Berdasarkan pantauan tim KKN kelompok 4 dari jurusan Farmasi Universitas Garut, mayoritas warga dengan kesadaran sendiri telah menjalankan protokol kesehatan, salah satunya dengan selalu memakai masker dan mengonsumsi berbagai obat maupun supplement. Menurut kementrian kesehatan republik Indonesia, masker yang biasa dipergunakan oleh golongan masyarakat yaitu masker sekali pakai tidak dapat dikategorikan sebagai masker medis, dikarena tidak diperuntukan untuk kegiatan medis, melainkan hanya pemakai sehari-hari di lingkungan desa Cikelet (Kementerian Kesehatan RI, 2020). Berdasarkan permasalahan tersebut, KKN kelompok 4 ingin memberikan edukasi kepada para warga mengenai, bagaimana sebaiknya membuang sampah dari masker sekali pakai yang sudah digunakan agar tidak menjadi sampah yang justru dapat membahayakan lingkungan dan kesehatan warga.

Salah satu cara yang dilakukan oleh tim Farmasi Universitas Garut dalam kegiatan PKM dan bersamaan dengan program KKN 2021 dengan memberikan penyuluhan dalam bentuk brosur kepada warga sekitar desa Cikelet. Diharapkan melalui kegiatan tersebut kesehatan lingkungan di desa tersebut menjadi lebih bersih dan lebih baik lagi ke depannya. Keberhasilan kegiatan ini nantinya sebagai wujud dari kepedulian berbagai pihak, tidak hanya masyarakat desa Cikelet saja, 
melainkan juga semua pihak yang telah berperan baik secara langsung maupun tidak langsung yang telah menyumbang berbagai ide kreativitas untuk kegiatan dan program lainnya.

\section{Metode}

Kegiatan ini merupakan non-eksperimental yaitu penelitian langsung kepada panelis yang merupakan masyarakat desa Cikelet yang diambil sebagai subjek dengan menggunakan instrumen kuesioner. Metode pengabdian yang digunakan adalah penyuluhan dengan tujuan membangun edukasi dan peningkatan kesadaran dan pengetahuan warga di desa Cikelet, yang dilaksanakan dengan beberapa tahapan. Kegiatan dilakukan melalui dua tahap yaitu tahap persiapan dan tahap pelaksanaan yang akan dijelaskan seperti di bawah ini

\section{Tahap Persiapan Tim Pengabdian}

1. Tim Pengabdian dari Fakultas Farmasi Uniga mengadakan rapat koordinasi tim untuk persiapan, dengan memperhatikan, mendengarkan permasalahan yang terjadi di desa Cikelet khususnya pemahaman mengenai cara membuang sampah masker sekali pakai dengan cara yang baik dan benar.

2. Tim pengabdian masyarakat melakukan koordinasi dengan tim lainnya karena profesi dari warga berbeda-beda sehingga mempengaruhi jam kerja warga. Selain itu juga dibahas persiapan edukasi terkait cara pelaksanaan dan penentuan jumlah peserta.

\section{Pelaksanaan Kegiatan}

Metode pengabdian yang digunakan adalah penyuluhan dengan tujuan membangun edukasi dan peningkatan kesadaran dan pengetahuan masyarakat Cikelet, yang dilaksanakan dengan beberapa tahapan.

1. Sebagai awal kegiatan, dilakukan pre-test online maupun manual angket mengenai pengetahuan tentang cara membuang sampah obat.

2. Penyuluhan dilaksanakan dengan pemberian materi berupa brosur dengan judul "Cara Membuang Sampah Masker Sekali Pakai di Desa Cikelet" dilanjutkan dengan diskusi.

3. Dari hasil kegiatan sosialisasi tersebut akan dilakukan evaluasi mengenai apakah ada peningkatan pengetahuan peserta melalui pre dan post test terhadap materi penyuluhan yang telah diberikan.

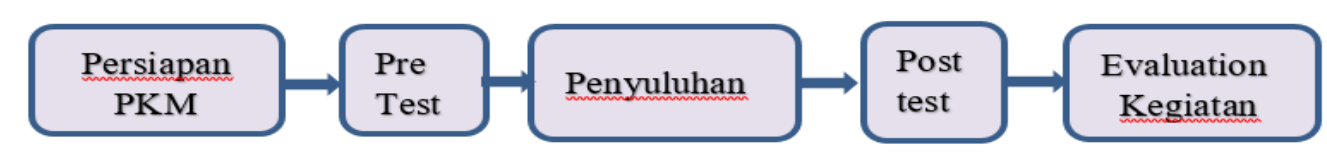

Gambar 1. Diagram kegiatan PKM di desa Cikelet. 


\section{Hasil dan Pembahasan}

Kegiatan sosialisasi "Cara membuang sampah masker sekali pakai", dimulai dari bulan September 2021. Mahasiswa S1 Farmasi yang melakukan sosialisasi tersebut berjumlah 6 orang. Sosialisasi dibagi menjadi beberapa tahapan yaitu ada yang langsung ke rumah warga. Dalam sosialisasi tersebutada beberapa kendala yang dihadapi diantara lain kurangnya keterbukaan para warga dalam menjawab kuisioner pre test maupun post test sehingga harus dipandu. Hal tersebut membuat tantangan tersendiri bagi Tim Farmasi Uniga agar komunikasi kesehatan yang diberikan bisa tersampaikan dengan baik.

Berikut ini adalah hasil persentasi kegiatan penyuluhan terhadap warga di desa Cikelet berdasarkan jenis kelamin, usia dan pendidikan.

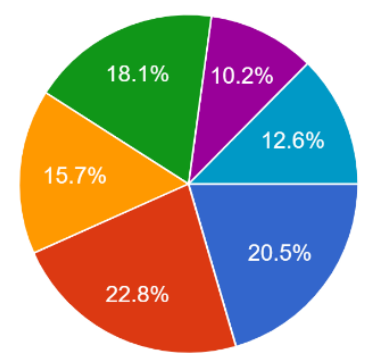

Perempuan, Usia 20 - 30 tahun

Laki-laki, Usia 20 - 30 tahun

Perempuan, Usia 31 - 40 tahun

Laki-laki, usia 31 - 40 tahun

Perempuan, Usia 41 - 50 tahun

Laki-laki, Usia 41 - 50 tahun

Gambar 2. Persentasi warga yang mengikuti penyuluhan berdasarkan jenis kelamin dan Usia

Kegiatan sosialisasi cara membuang sampah masker sekali pakai dilakukan dengan cara mengunjungi langsung atau mendatangi warga yang sedang melakukan aktivitas di luar atau lapangan terbuka. Hasil yang didapatkan dalam PKM ini menunjukkan bahwa 127 panelis yang mengikuti penyuluhan yang dilakukan oleh tim Farmasi Uniga merupakan laki-laki sebesar 38,5\% dan perempuan dengan jumlah $61,5 \%$, dimana usia terbanyak yang mengikuti penyuluhan ini berada pada posisi 20-30 tahun. Usia tersebut merupakan usia produktif dan menuntut warga untuk selalu menggunakan masker selama pandemi.

Peserta penyuluhan merupakan masyarakat desa Cikelet dengan beragam profesi mulai dari Ibu rumah tangga sampai dengan pegawai dengan total 127 orang. Untuk mengetahui ukuran atau jumlah sampel minimal yang dapat digunakan pada kegiatan pre test online ini digunakan rumus Slovin (Setiyanti, 2014).

$$
\mathrm{n}=\mathrm{N} \backslash 1+\mathrm{Ne}^{2}
$$

Keterangan : $\mathrm{n}=$ Ukuran sampel; $\mathrm{N}=$ Ukuran populasi; $\mathrm{e}=$ Error margin (kelonggaran ketidaktelitian. Misalnya $\mathrm{Sig}=0,05$ )

Pada kegiatan yang dilakukan ukuran populasi atau jumlah populasi peserta sebanyak 127 peserta, sehingga dengan menggunakan rumus Slovin, banyaknya sampel atau ukuran sampel minimal yang dapat digunakan adalah $: \mathrm{n}=127 / 1+127$ $(0,05)^{2}=96$ peserta. Berdasarkan perhitungan tersebut jumlah panelis minimal 
yang harus digunakan yaitu 96 panelis dari 127 total peserta penyuluhan. Jumlah peserta yang mengisi pre test online sebanyak 96 peserta. Nilai tersebut melebihi batas minimal panelis yang harus digunakan.

Pendidikan

127 responses

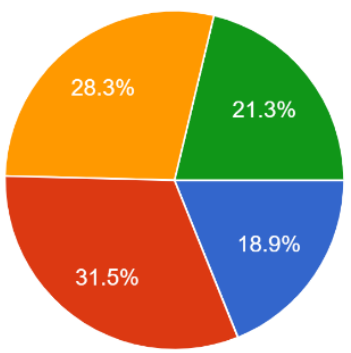

Pekerjaaan

127 responses

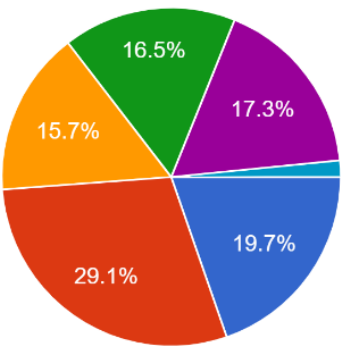

SMP

SMU/SMK

D1, D2, D3. S1, S2

SD

Gambar 3. Persentasi warga yang mengikuti penyuluhan berdasarkan pendidikan dan pekerjaan

Gambar 3 di atas menjelaskan karakteristik panelis berdasarkan pekerjaan dan pendidikan, dimana jenis pendidikan tertinggi ditingkat sekolah menengah umum dan profesi terbanyak adalah ibu rumah tangga sebesar 29,1\% dan yang paling sedikit berprofesi sebagai pegawai $15,7 \%$, hal ini menunjukkan keberagaman profesi dan pendidikan dari panelis yang mengikuti pre dan post test.

Jenis masker yang anda gunakan?

127 responses

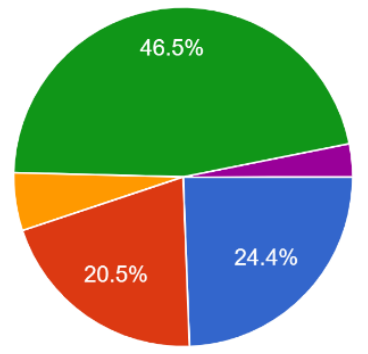

Masker kain

Masker Medis (1-3 Lapis)

Masker N95

Kombinasi, Kadang kain, kadang medis

DLL 
[29] Novriyanti Lubis, dkk /To Maega: Jurnal Pengabdian Masyarakat, Vol.5; No.1; Februari, 2022

Bagaimana kebiasaan menggunakan masker selama pandemi covid 19 ?

127 responses

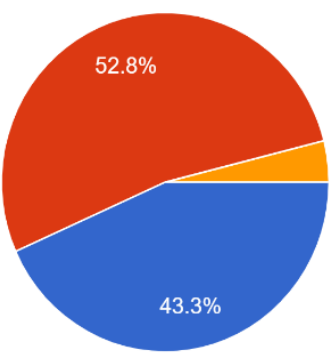

Selalu menggunakan jika keluar rumah

Kadang-kadang, tergantung kondisi

Tidak pernah menggunakan

Gambar 4. Perilaku Warga Dalam Menggunakan Masker

Penggunaan masker saja selama pandemi Covid 19 tidak cukup untuk dapat melindungi diri dari virus corona (World Health Organization, 2020). Berdasarkan kuisioner, warga desa Cikelet cendrung menggunakan masker kombinasi dalam kesehariaannya, yaitu sebesar $46,5 \%$ artinya terkadang mereka menggunakan masker sekali pakai, masker scuba maupun masker lain. Jika melihat efek dari penggunaan masker, maka organisasi kesehatan lingkungan menyarankan untuk tidak menggunakan masker sekali pakai, karena akan membuat sampah masker semakin banyak (Adyani, 2021). Mengenai kebiasaan warga dalam menggunakan masker lebih 50\% warga akan memakai masker tergantung dari kondisi, jika berada di keramaian maka akan menggunakannya. Hal ini tidak sesuai dengan himbauan dari pemerintah, dimana sebaiknya jika seseorang bila belum di vaksinasi sebaiknya untuk selalu senantiasa menggunakan masker demi perlindungan diri tahap awal dan dikarenakan Usai divaksin, seseorang tidak otomatis kebal Corona (Arifia, 2021).

Sebelum sosialisasi bagaimana cara anda membuang sampah masker medis ?

$40 / 124$ correct responses

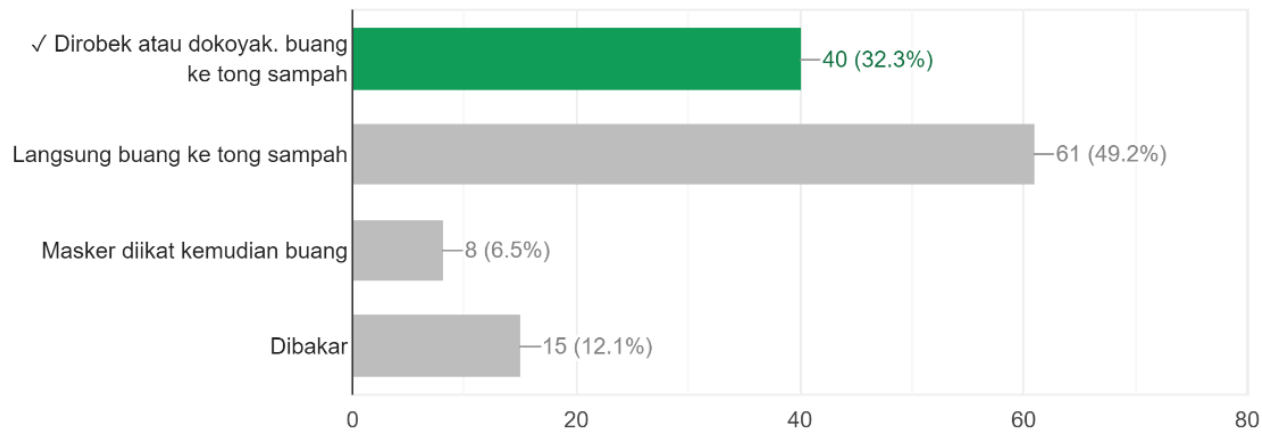

Sebelum Sosialisasi 
Setelah Sosialisasi untuk selanjutnya bagaimana cara anda membuang sampah masker yang paling baik dan benar?

$95 / 127$ correct responses

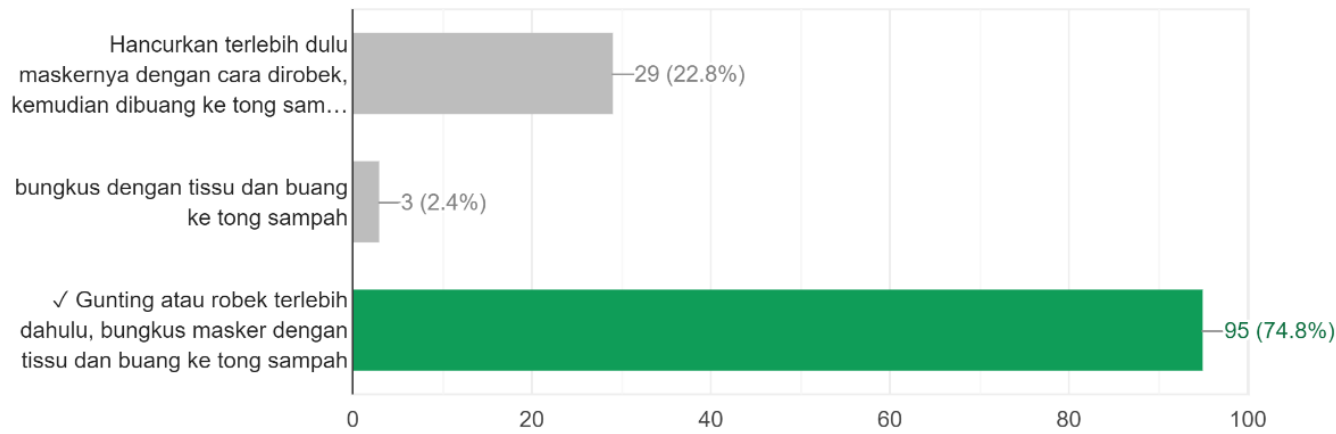

Sesudah Sosialisasi

Sebelum Sosialisasi apakah anda tahu cara paling baik membuang sampah masker medis? 127 responses

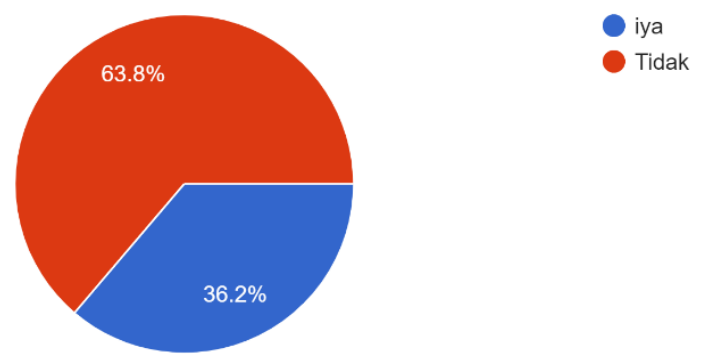

Sebelum Sosialisasi

Setelah sosialisasi apakah anda akan membuang sampah masker sekali pakai dengan baik dan benar?

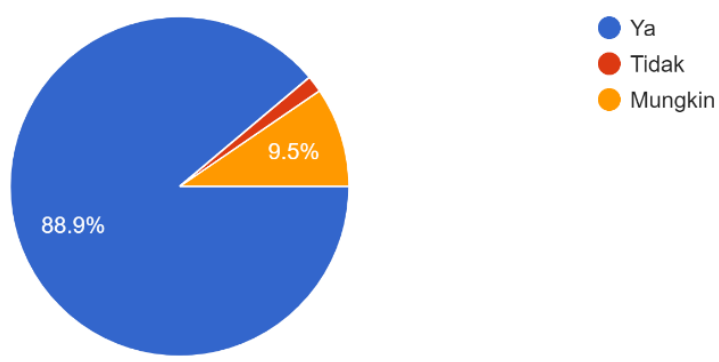

\section{Sesudah Sosialisasi}

Gambar 5. Prilaku Warga dalam membuang sampah masker

Dari hasil penyuluhan, data pre test dan post test, didapatkan hasil bahwasanya 61 orang warga desa Cikelet ketika membuang sampah masker sekali pakai langsung dibuang saja ke tong sampah, hal ini kurang sesuai dengan anjuran dari kemenkes. Untuk itu disinilah peran dari kelompok 4 KKN dari tim Farmasi Uniga, memberikan penyuluhan kepada warga, bahwa menurut kemenkes masker sebaiknya dirusak terlebih dahulu dengan cara dirobek atau digunting, sehingga tidak dapat digunakan lagi kemudian buang ke tong sampah (Kementerian 
Kesehatan RI, 2020). Sebelum sosialisasi hanya 36.2\% warga yang tahu cara membuang sampah masker sekali pakai dengan cara yang baik dan benar. Setelah sosialisasi kesadaran warga menngenai cara membuang sampah masker naik menjadi 88,3\%. Lebih lanjut, tim Farmasi memberikan penyuluhan secara prosedur lengkap tahapan membuang sampah masker sekali pakai adalah dikumpulkan sampah maskernya, kemudian diberikan desinfektan, dirobek atau digunting, selanjutnya dibungkus dengan tissu atau plastik, dan terakhir dibuang ke tong sampah (Adyani, 2021). Kelompok 4 KKN desa Cikelet juga memberikan informasi kepada para warga untuk waspada terhadap masker medis palsu. Dimana ciri-ciri dari masker medis asli adalah ada izin edar dari Kemenkes, bahan baku dari non woven spunbond dan lainnya (Nurhanisah, 2021).

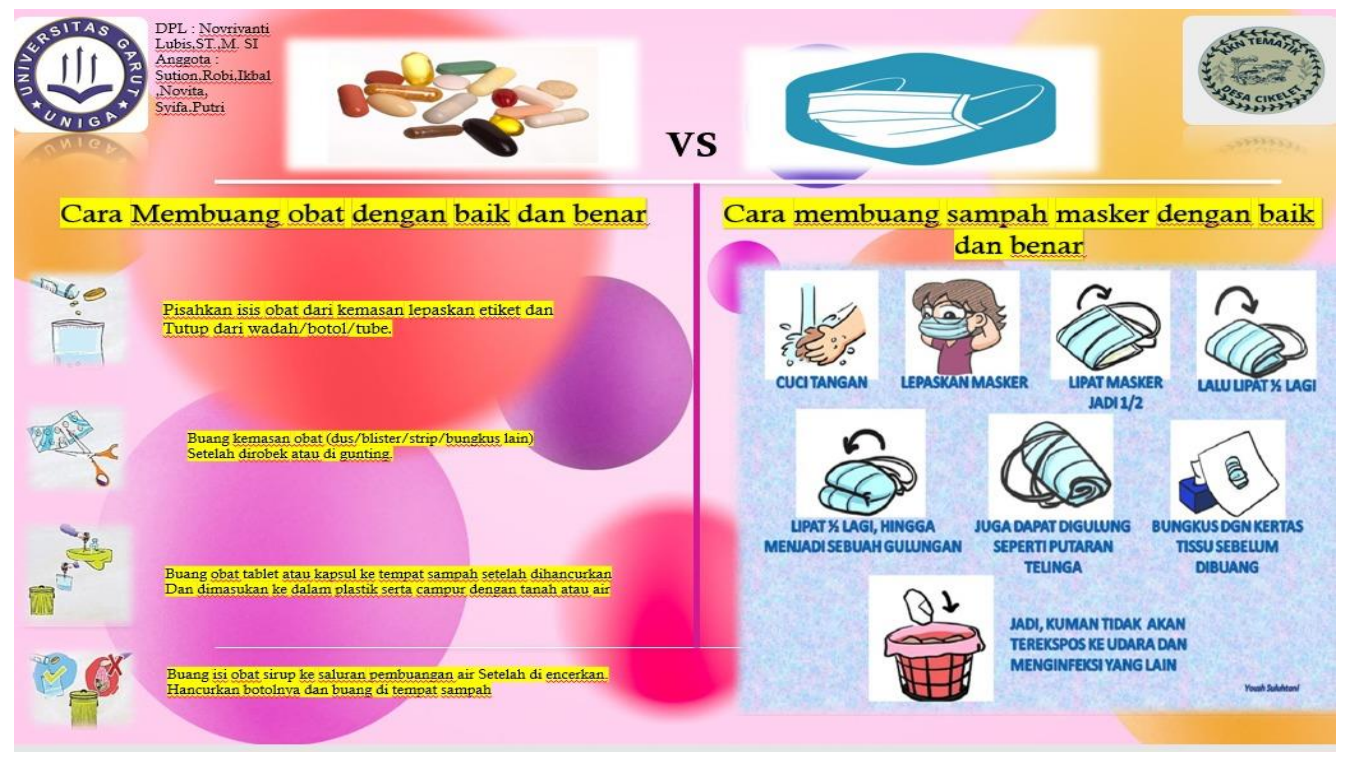

Gambar 6. Brosur Penyuluhan tentang sampah masker medis

Dalam menyampaikan informasi kesehatan untuk mempermudah penyampaian pesan salah satu media kesehatan yang dapat digunakan adalah melalui poster, brosur, dan model buku bergambar (Apriyani \& Sumerti, 2015). Tim Farmasi Uniga memilih media brosur dengan pertimbangan penyuluhan yang diberikan kepada warga desa Cikelet akan lebih efektif. Menurut pakar pendidikan, pemberian penyuluhan dengan media video atau brosur dapat mempermudah untuk memahami terhadap isi materi yang diberikan, dikarena tampilan dari brosur sangat menarik, selain itu juga dapat membaca informasi yang diberikan secara berulang (Nurlila et al., 2016). Melalui sosialisasi ini, tim KKN berupaya untuk mengingatkan para warga untuk senantiasa menggunakan masker dan membuang sampah masker sekali pakai sesuai dengan prosedur. 


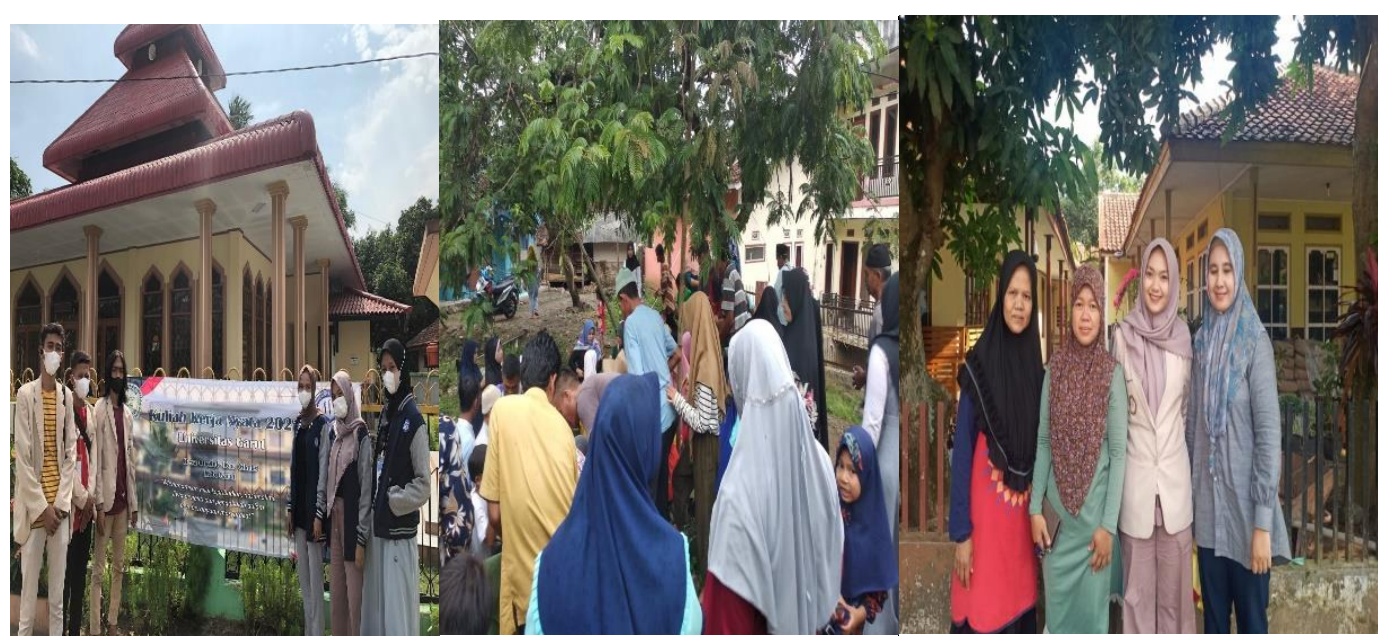

Gambar 7. Dokumentasi Kegiatan PKM dari Kelompok 4 KKN desa Cikelet

Gambar 7 menunjukan dokumentasi kegiatan PKM yang telah dilakukan oleh kelompok 4 KKN desa Cikelet. Secara umum, masyarakat desa Cikelet menyambut baik penyuluhan yang telah dilakukan oleh tim Farmasi Uniga khususnya mengenai cara membuang sampah masker sekali pakai dengan baik dan benar dikarenakan pandemi Covid 19 yang masih berlangsung sampai sekarang mengharuskan warga untuk selalu menggunakan masker demi mengurangi penyebaran virus corona (Lubis, 2021). Selanjutnya warga desa Cikelet diharapkan bisa merasakan manfaat dari penyuluhan tersebut.

\section{Kesimpulan}

Dari hasil kegiatan PKM 2021 di desa Cikelet melalui program KKN dengan tema penyuluhan atau sosialisasi dengan judul 'Cara membuang sampah masker sekali pakai" terjadi peningkatan pengetahuan wrga tersebut setelah menerima penyuluhan dari tim Farmasi Uniga. Untuk mengetahui keberhasilan dari program tersebut sebelumnya telah dilakukan pre test dan post test. Penyuluhan diberikan kepada 127 warga dari berbagai tingkatan usia, pendidikan dan pekerjaan. Penyuluhan kesehatan menggunakan brosur dan hasil kegiatan menunjukkan sebagian dari warga sudah memahami konsep mengenai cara membuang masker sekali pakai dengan baik dan benar. Diharapkan kedepannya para warga senantiasa mempraktekkan ilmu yang telah didapatkan selama penyuluhan. Kegiatan PKM mahasiswa Farmasi Uniga, dari kelompok KKN desa Cikelet secara keseluruhan semua rangkaian kegiatan yang direncanakan sudah terlaksana dengan lancar dan hasil yang sesuai dengan harapan.

\section{Daftar Pustaka}

Adyani, V. (2021). Pengelolaan Sampah Masker Sekali Pakai. P2KLH. https://www.dlhk.jogjaprov.go.id/pengelolaan-sampah-masker-sekali-pakai Apriyani, S. A. K., \& Sumerti, N. N. (2015). Keberhasilan Pbnyuluhan Kesehatan 
Gigi Menggunakan Media Poster Dan Media Model Pada Siswa Sd Negeri 6 Kawan Bangli Tahun 2Oi4. Jurnal Kesehatan Gigi (Dental Health Journal), $3(1), 11-15$.

Arifia, I. (2021). Usai Vaksin, Masker dan Protokol Kesehatan Tetap Wajib Dijalankan. Unair News. http://news.unair.ac.id/2021/04/06/usai-vaksinmasker-dan-protokol-kesehatan-tetap-wajib-dijalankan/

Azizah, U. (2012). Implementasi Program Pengelolaan Sampah Berbasis Komunitas Di Kelurahan Sambiroto Kecamatan Tembalang Kota Semarang. Media Neliti, 10(9), 32.

Didiharyono, D., Tenrigau, A. M., \& Marsal, M. (2018). Pemanfaatan Sampah Plastik Untuk Dijadikan Bantal Yang Berkualitas Dan Bernilai Ekonomis Di Desa Tolada Kecematan Malangke Kabupaten Luwu Utara. To Maega: Jurnal Pengabdian Masyarakat, 1(1), 8-13.

Inferm, W. (2021). Begini Cara Kelola Limbah Masker di Masyarakat Untuk Cegah Penularan COVID-19. Infeksi Emerging. https://infeksiemerging.kemkes.go.id/warta-infem/begini-cara-kelola-limbahmasker-di-masyarakat-untuk-cegah-penularan-covid-19

Kementerian Kesehatan RI. (2020). Pedoman Kelola Limbah Masker Masyarakat. In Kemenkes RI (p. 1).

Lubis, N. (2020). Gerakan Desa Sadar Bahaya Covid 19: Pengabdian Pada Masayrakat Desa Cilawu Kabupaten Garut. Jurnal Kreativitas Pengabdian Kepada Masyarakat, 3(2), 480-494.

Nurlila, R. U., Fua, J. La, \& Meliana. (2016). Pengaruh Pendidikan Kesehatan terhadap Pengetahuan tentang Kesehatan Gigi pada Siswa di SD Kartika XX10 Kota Kendari tahun 2015. Jurnal Al-Ta'dib, 9(1), 94-119. http://ejournal.iainkendari.ac.id/al-tadib/article/view/504/491

Piat. (2021). Sistem Pengelolaan Limbah Masker Sekali Pakai dan Sarung Tangan Plastik Ramah Lingkungan. Piat UGM. https://piat.ugm.ac.id/2021/04/29/dumask-sistem-pengelolaan-limbahmaskersekali-pakai-dan-sarung-tangan-plastik-ramah-lingkungan/

Saptoyo, R. D. A. (2021). Tiap Semenit Terdapat 2,8 Juta Limbah Masker Sekali Pakai di Bumi. Kompas.Com. https://www.kompas.com/tren/read/2021/05/11/120500265/tiap-semenitterdapat-2-8-juta-limbah-masker-sekali-pakai-di-bumi?page=all

Setiyani L. 2014. Research Methods Information Technology. International Encyclopedia of Human Geography. https://doi.org/10.1016/B978008044910-4.00180-2

World Health Organization, W. (2020). Anjuran mengenai penggunaan masker dalam konteks COVID-19. World Health Organization, April, 1-17. https://www.who.int/docs/default-source/searo/indonesia/covid19/anjuranmengenai-penggunaan-masker-dalam-konteks-covid-19-june-20.pdf?sfvrsn

Yuli Nurhanisah. (2021). Hati-Hati Masker Medis Palsu. Indonesia Baik. https://indonesiabaik.id/infografis/hati-hati-masker-medis-palsu 